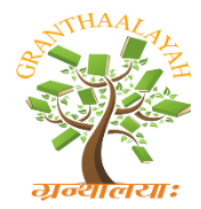

Science

\title{
INFLUENCE OF MATURATION ON ENGINEERING PROPERTIES OF THREE BEAN (PHASEOLUS VULGARIS L.) VARIETIES, RELATED TO MACHINE DESIGN
}

\author{
Engr. Oghenerukevwe Prosper ${ }^{1}$, Hilary Uguru *2 \\ ${ }^{1}$ Department of Mechanical Engineering, Delta State Polytechnic, Ozoro, Nigeria \\ ${ }^{* 2}$ Department of Agricultural and Bio-Environmental Engineering, Delta State Polytechnic, \\ Ozoro, Nigeria
}

\begin{abstract}
Knowledge of the engineering properties of seeds is essential for the design and development of their harvesting, handling and processing machines. Engineering properties of post-harvest bean seeds have been well studied, but the influence of maturation on the engineering properties of most crops including bean seeds have not been fully studied. The objective of this study was to determine the effect of maturity stage on some engineering properties of three bean varieties (butter, brown and white cowpea) grown in Nigeria. The bean seeds were harvested at 15, 20 and 25 days after flowering, and these engineering properties; average thousand seed mass, size, volume, geometric mean, sphericity, surface area, arithmetic mean, bulk density, true density, porosity, coefficient of static friction, hydration capacity and coefficient, and swelling capacity and coefficient were investigated. The results showed that maturity stage of the bean seeds significantly $(\mathrm{P} \leq 0.05)$ affects all their studied. Correlations between the engineering properties and maturity stage for the three bean varieties were relatively high. Over the course of a maturation time, the moisture content declined from 83.40 to $42.31,86.59$ to 46.73 , and 87.15 to $47.82 \%$ (wb) for butter, white cowpea and brown bean seeds respectively. From the results, the ideal period for bean pods harvest, processing and handling for the three bean varieties is between 20 to 25 days after anthesis, since the seeds will be having maximum dry weight and higher viability. The results gotten from this research are important in the design and development of processing and handling machines.
\end{abstract}

Keywords: Butter Bean; Cowpea; Physical Properties; Functional Properties; Maturation; Moisture Content.

Cite This Article: Engr. Oghenerukevwe Prosper, and Hilary Uguru. (2018). "INFLUENCE OF MATURATION ON ENGINEERING PROPERTIES OF THREE BEAN (PHASEOLUS VULGARIS L.) VARIETIES, RELATED TO MACHINE DESIGN." International Journal of Research - Granthaalayah, 6(5), 93-113. 10.29121/granthaalayah.v6.i5.2018.1432. 


\section{Nomenclature \\ L Length (mm) \\ W Width (mm) \\ $\mathrm{D}_{\mathrm{a}}=$ Arithmetic mean $(\mathrm{mm})$ \\ $\mathrm{D}_{\mathrm{g}}=$ Geometric mean $(\mathrm{mm})$ \\ $\phi \quad$ Sphericity (\%) \\ $\rho b \quad$ Bulk density $\left(\mathrm{kg} / \mathrm{m}^{3}\right)$ \\ pt True density $\left(\mathrm{kg} / \mathrm{m}^{3}\right)$ \\ DAF Days after flowering \\ $\mathrm{S}_{\mathrm{c}} \quad$ Swelling capacity}

$\begin{array}{ll}\text { T } & \text { Thickness }(\mathrm{mm}) \\ \mathrm{S} & \text { Surface area }\left(\mathrm{mm}^{2}\right) \\ \text { V } & \text { Volume }\left(\mathrm{mm}^{3}\right) \\ \text { D } & \text { Diameter }(\mathrm{mm}) \\ \mathrm{H} & \text { Height }(\mathrm{mm}) \\ \varepsilon & \text { Porosity } \\ \psi & \text { Angle of repose } \\ \mathrm{H}_{\mathrm{c}} & \text { Hydration capacity }\end{array}$

\section{Introduction}

Common bean (Phaseolus vulgaris L.) is a plant species widely cultivated due to its good nutritional composition (high protein content in dry seed and a good source of fibre in snap bean) and its high market value is consumed either as a dry bean or as a snap bean (fresh vegetable). Consumers have progressively shown specific preferences for various combinations of size and shape of bean seeds and pods and the market reflects this trend by giving preference to types of good quality rather than high yield (Santalla et al., 1999; Marzo et al., 2002). Common bean is a major grain legume crop in the world (Leterme and Carmenza, 2002) and widely consumed in Africa (Singh et al., 2004; HarvestPlus, 2014). Its third in importance after soybean and peanut as a legume crop, but first in direct human consumption (Broughton et al., 2003). Beans have been extensively cultivated under different climatic conditions and by producers with different technology levels. Thus, to obtain higher profitability, it would be necessary to search for varieties adapted to the cultivation conditions and with high grain yield to meet consumer demands (Carneiro et al., 2005). Beans present great variety in color, size, chemical composition and hardness, depending on the cultivar to which they belong. These differences come from intrinsic factors (genotype, which is partially responsible for the differences between cultivars and varieties) or from extrinsic factors such as storage conditions, type of cultivation soil, agronomic practices and climatic and technological factors (González et al., 2005; Aghkhani et al., 2012). Bean seeds form a major staple food in rural and urban areas in Nigeria, rich in significant amounts of protein, minerals and vitamins. They contain reasonable amount of protein and their mineral contents: calcium and iron are higher than that of meat, fish and egg and the iron content equates that of milk (Agbogidi and Egho, 2012). Besides its health-related benefits, beans are inexpensive, considerably cheaper than rice or any other dietary fibre type (Ayenlere et al., 2012).

Information on the physical properties of bean seed such as their dimensions, porosity, volume, density (true and bulk) is important in designing the equipment for harvest, transport, storage, processing, cleaning, hulling, and milling (Akaaimo and Raji, 2006; Coşkuner and Karababa, 2007). One hundred seeds mass is useful in determining the equivalent diameter that can be used in the theoretical estimation of seed volume and in cleaning using aerodynamic forces (Lvin, 1971). The true density indicate that the seeds are heavier than water and this characteristic can be used to design separation or cleaning process for the beans; while bulk density is used as an indication of quality during storage of beans (Mpotokwane et al., 2008). Porosity is used to calculate the rate of aeration and cooling, drying and heating and the design of heat exchangers and other similar equipment for bean handling (Asoegwu et al., 2006). Previous researchers such 
as: Altuntas and Demirtola (2007) and Nciri et al., (2014) have researched on some engineering properties of bean (Phaseolus vulgaris L.) seeds. The hydration capacity of a substance is a measure of the relative amount of water that can be taken up by the substance while the swelling capacity is a measure of increase in the volume of the substance sequel to hydration (Isah et al., 2012). According to some authors, soaking time is directly related to cooking time, which tends to decrease, as beans remain immersed (Rodrigues et al., 2005a and 2005b). Water-holding capacity and cooking time of beans were evaluated by Rodrigues et al. (2005a and 2005b) and these showed that cooking time decreased as soaking time increased. Romano et al. (2005) studying the hydration curve and cooking time, verified that after three hours of soaking, the cooking time of the cultivars Pérola and Guapo Brilhante was reduced to half.

Despite comprehensive literature review on some engineering properties of bean seeds, there is a dearth of information on the effect of maturation on the engineering properties of bean seeds. Any data obtained from other countries cannot be directly ploughed into the design of planting, harvesting, handling and processing machines, because most engineering properties of bean seeds are clearly influenced by both environmental and genetics factors (Nciri et al., 2014). Therefore, the objective of this study is to provide data about the engineering properties of three bean varieties (butter, Brown and white cowpea), as they are influenced by their maturity age, which will be useful in the design of harvesting, handling and processing machineries.

\section{Materials and Methods}

\subsection{Plant materials}

The three bean (Phaseolus vulgaris L.) varieties (butter, Brown and white cowpea) were planted at the research farm of Delta State Polytechnic, Ozoro, Delta state, Nigeria, on January, 2018 and harvested April, 2018. The bean seeds were selected and cleaned manually, to ensured that the seeds were free of dirt, broken ones, and other foreign materials.

\subsection{Moisture Content (Wet Basis) Determination}

The moisture content (\% w.b) was determined with hot air oven drier using the method recommended by (AOCC, 2000) using Equation 1. Bean seeds weighing $10 \mathrm{~g}$ were placed in a moisture can and placed in an electric oven set at the temperature of $105^{\circ} \mathrm{C}$. the weight of the bean seeds was taken even 2 hours until a stable weight was obtained. The result of moisture content was calculated (Equation 1).

$M C=\frac{W_{2}-W_{3}}{W_{2}-W_{1}} \times 100$

\subsection{Dimensional Properties}

A total of forty bean seeds were randomly selected from each variety, and their three principal dimensions ( $\mathrm{L}, \mathrm{W}$ and $\mathrm{T}$ ) measured using a digital venier caliper (accuracy of $0.01 \mathrm{~mm}$ ). From the dimensions obtained (for $\mathrm{L}, \mathrm{W}$ and $\mathrm{T}$ ), the geometric mean diameter, arithmetic mean diameter, surface area, sphericity and volume of the seed can be calculated. 


\section{Geometric Mean Diameter}

The geometric mean was determined based on the measured dimensions of bean seeds samples using Equation 2 (Mpotokwane et al., 2008).

$D_{g}=\sqrt[3]{L \times B \times T}$

\section{Arithmetic Mean Diameter}

The arithmetic mean of the bean seed was obtained using equation 3 (Mpotokwane et al., 2008).

$D_{a}=\frac{(L+W+T)}{3}$

\section{Sphericity}

The sphericity $(\varphi)$ was calculated as a function of the three principal dimensions as shown in the equation (4) below (Mohsenin, 1986).

$\phi=\frac{\sqrt[3]{L \times B \times T}}{L} \times 100$

\section{Surface Area}

The surface area, also expressed as the size, of the seed was calculated using the relationship in the equation (5) below (Mohsenin, 1986).

$S=\pi D_{g}^{2}$

\section{Volume}

The volume of the seeds was calculated using the relationship presented in equation 6 (Mohsenin, 1986).

$V=\frac{\pi D g^{3}}{6}$

\subsection{Gravimetric Properties Determination}

\section{Thousand Seed Mass (TSM)}

The one thousand seed mass (TSM) of the two bean varieties was measured by counting 100 seeds from each variety and weighing them in an electronic balance to an accuracy of $0.001 \mathrm{~g}$. To evaluate the thousand seed mass, the result of the 100 seeds is multiplied by 10 to give mass of 1000 bean seeds.

\section{Bulk Density}

The bulk density of the seeds was determined using the mass/volume relationship, by filling an empty plastic container of predetermined volume $\left(500 \mathrm{~cm}^{3}\right)$, by pouring from a constant height, striking off the top level and weighing (Ghasemi et al., 2008).

$$
\rho \mathrm{b}=\frac{M a}{V}
$$




\section{True Density}

The true density of seeds was determined by using the liquid displacement method. Toluene $\left(\mathrm{C}_{7} \mathrm{H}_{8}\right)$ was used in place of water because it has lesser extent absorb by seed. Fifty grams of the seed were filled in a calibrated pipe and the displaced toluene was measurement from the pipe. True density was obtained as the ratio of seeds weight to the volume of displaced liquid.

\section{Porosity}

The porosity of the bean seeds which depends on their bulk and true densities, is calculated by equation 8 (Mohsenin, 1986).

$\varepsilon=\left(1-\frac{\text { Bulk density }}{\text { True density }}\right) \times 100$

\subsection{Frictional Properties}

\section{Coefficient of Static Friction}

The coefficient of static friction $(\mu)$ was obtained with respect to three surfaces: plywood, laminate, and glass surfaces. These materials are commonly used in transportation, storage and handling operations, construction of storage and drying bins. An open-ended hollow cylinder of $50 \mathrm{~mm}$ diameter and $50 \mathrm{~mm}$ height, was filled with the seeds and placed on an adjustable tilting table. The hollow cylinder was pulled up slightly to avoid contact between it and the friction surface. The tilting surface was raised gradually by means of a screw device; the angle of tilt ( $\alpha$, degree) at which the cylinder with seeds just began to slide down was recorded as the angle of static friction (Akaaimo and Raji, 2006).

$\mu=\tan \theta$

\subsubsection{Angle of Repose}

The angle of repose $(\psi)$ was determined by using a hollow cylindrical mould of $100 \mathrm{~mm}$ diameter and $150 \mathrm{~mm}$ height. The cylinder was placed on a wooden table, filled with bean seed and raised slowly until it forms a cone of seeds. The diameter and height of the cone were recorded. The angle of repose $(\psi)$ was calculated by the fallowing equation (Mullah, 1992).

$\psi=\tan ^{-1} \frac{2 H}{D}$

\subsubsection{Functional Properties}

\section{Hydration Capacity}

Fifty bean seeds (uniform size and shape) were soaked overnight (16 hours), after which the water was drained. The soaked seeds were blotted dry and weighted again. After soaking, the beans were cut into half along the fissure, and free water was removed using a blotting paper. Hydration capacity was calculated as change in weight per number of seeds as given in the equation 11.

$H_{c}(g /$ seed $)=\frac{\left(M_{a}-M_{b}\right)}{N}$

Where $\mathrm{M}_{\mathrm{b}}$, weight of seeds before soaking; $\mathrm{M}_{\mathrm{a}}$, weight of seeds after soaking; $\mathrm{N}$, number of seeds. 


\section{Swelling Capacity}

The initial volume of fifty bean seeds (uniform size and shape) was noted in a graduated cylinder (Bishnoi and Khetarpaul, 1983) and the bean seeds were soaked overnight. Swelling capacity (Sc) was calculated as change in volume per number of as shown in the equation 12.

$S_{c}(m L / s e e d)=\frac{\left(V_{a}-V_{b}\right)}{N}$

Where $\mathrm{V}_{\mathrm{b}}$, volume of seeds before soaking; $\mathrm{V}_{\mathrm{a}}$, volume of seeds after soaking; $\mathrm{N}$, number of seeds.

\section{Hydration and Swelling Coefficients}

Fifty seeds of each bean variety were soaked in distilled water for 16 hours and the volume of the bean seeds was estimated before and after soaking by determination of displaced water. After soaking, the beans were cut into half along the fissure, and free water was removed using a blotting paper. The hydration coefficient was calculated as the percentage increase in weight of beans. The swelling coefficient was calculated as the percentage increase in volume of beans after soaking (Nciri et al., 2014).

$H_{\text {coefficient }}=\frac{M_{a}}{M_{b}} \times 100$

$S_{\text {coefficient }}=\frac{V_{a}}{V_{b}} \times 100$

\subsection{Data Analysis}

The data gotten from this research were subjected to analysis of variance (ANOVA) using SPSS version 22 (SPSS, IBM, Chicago USA) and means were separated using the Duncan multiple range test. Significance will be accepted at $95 \%$ confidence interval $(p<0.05)$. Total of twenty replica were recorded and the average determined.

\section{Results and Discussion}

\subsection{Seed Moisture Content}

The presentation in Figure 1 results showed that there is significant $(\mathrm{P}<0.05)$ differences in the moisture content of the three bean varieties for the three maturity stages. From the results (Figure 1), the moisture content of the three bean varieties moisture declined with increased in maturity stage from $15 \mathrm{DAF}$ to $25 \mathrm{DAF}$; and followed same behaviour during maturity. Seed moisture content has also been used as an index of optimum harvest time (Bedance et al., 2006; Demir and Ellis 1993). The pattern of declining seed moisture content during seed development was similar to that reported in marrow (Demir and Ellis, 1993) and spring barley (Pieta and Ellis, 1991). According to (Gonçalves et al., 2005), the total moisture content decreases in the course of maturity, this reduction in moisture content tends to cause an increase in firmness, as fruits tend to lose flexibility, when they lose water. The coefficient of determination $\left(\mathrm{R}^{2}\right)$ and correlation $(\mathrm{r})$ values obtained from the regression relationship between the moisture content and maturity stage for the three bean varieties are presented in Table 1. 


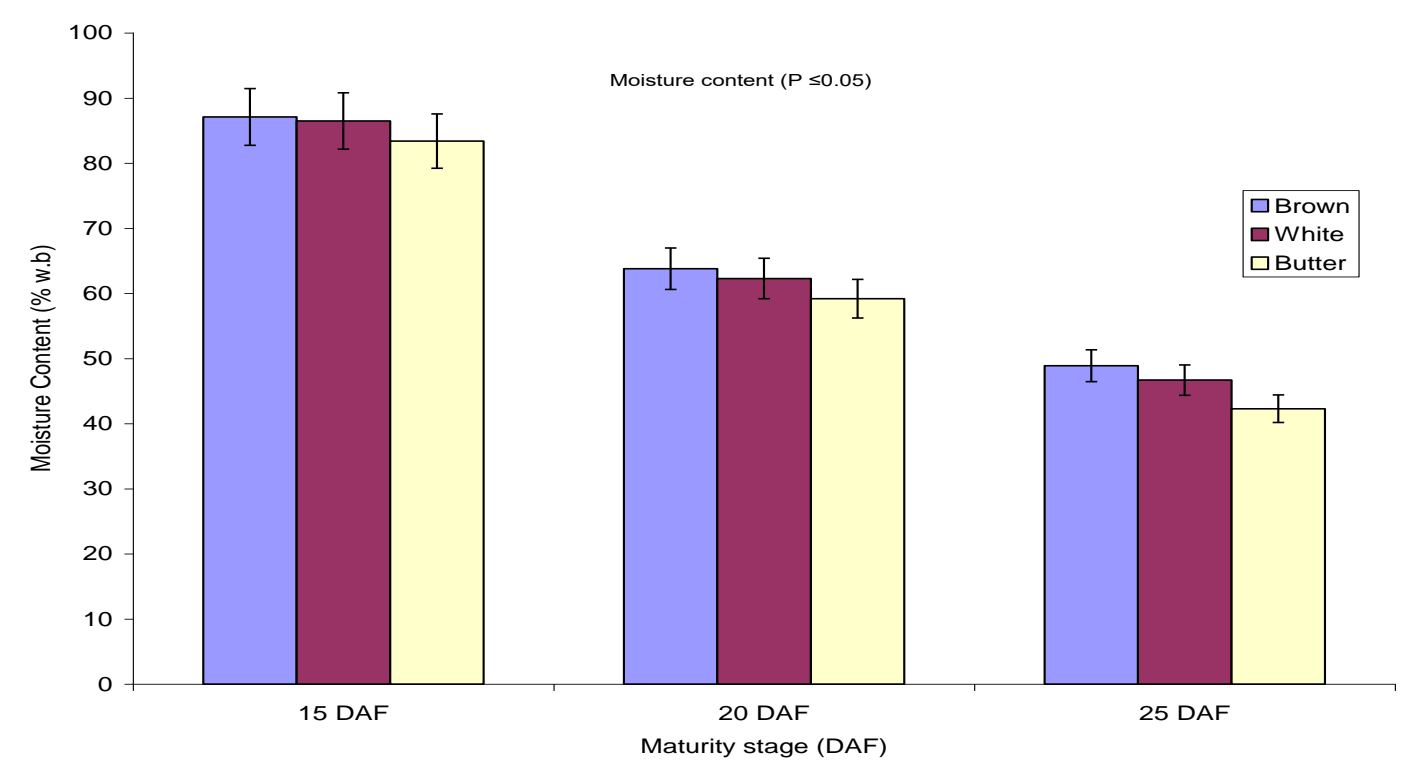

Figure 1: Influence maturity stage on bean seed moisture content

Table 1: Regression equations moisture content as function of maturity stage with their respective coefficient of determination $\left(\mathrm{R}^{2}\right)$ and correlation $(\mathrm{r})$

\begin{tabular}{|l|l|l|l|l|}
\hline Parameter & Bean variety & Linear equation & $\mathbf{R}^{2}$ & $\mathbf{r}$ \\
\hline Moisture content & White & $\mathrm{y}=-19.9 \mathrm{x}+104.97$ & 0.984 & -0.992 \\
\hline & Butter & $\mathrm{y}=-20.55 \mathrm{x}+102.73$ & 0.989 & -0.994 \\
\hline & Brown & $\mathrm{y}=-1.85 \mathrm{x}+89.367$ & 0.867 & -0.992 \\
\hline
\end{tabular}

\subsection{Seed Size and Dimensional Properties}

The analysis of variances (ANOVA) of the dimensional properties of the bean seeds are presented in Table 2. As shown in Table 2, maturity stage had significant $(\mathrm{P} \leq 0.05)$ effect on all the dimensional properties of the three varieties of bean seeds. The detail evaluation of length, width, thickness, arithmetic mean, geometric mean, surface area, volume and sphericity of the bean seeds are reported in Table 3; while their respective coefficient of determination $\left(\mathrm{R}^{2}\right)$ and correlation $(\mathrm{r})$ values presented in Table 4 . All the parameters investigated increased significantly $(\mathrm{P} \leq 0.05)$, as maturity period increases from $15 \mathrm{DAF}$ to $25 \mathrm{DAF}$ (Table 2). In reference to Table 3, there was linear increase in the length of the bean seeds with increased in maturation; and white bean was the highest in seed Length while butter bean was the lowest, this difference in seeds length may be due to genetic differences (Hu et al., 2013). From the results, the sphericity of the bean seeds was at the range of 74 to $76 \%$ at 25 DAF; a litter bit higher than what was reported for kidney beans (61.03-61.28 \%) by Altuntas and Demirtola (2007). The closer the sphericity to 1.0, the higher the tendency to roll about any of the three axes and the closer the ratio of thickness to width to 1.0, the higher the tendency to rotate with reference to the major axis (Akaaimo and Raji, 2006). This tendency to either roll or slide is very important in the design of hoppers and de-hulling equipment for the seed, because most flat seeds slide easier than spherical seeds which roll on structural surfaces (Ixtaina et al., 2008; Ijadunola, 2015). From the values shown in Table 3, it can be comprehended that the increment in maturity stage from $15 \mathrm{DAF}$ to $25 \mathrm{DAF}$, increased of the volume and size 77.28, 78.87 and $76.05 \%$, from white, butter and Brown beans seeds respectively. 
Physical properties of agriculturally valuated seed materials are important in designing the equipment for harvest, transport, storage, processing, cleaning, hulling, and milling (Akaaimo and Raji, 2006; Coskuner and Karababa, 2007; Sirisomboon et al., 2007). Size of bean seeds is considerably crucial parameter in terms of designing the seed metering mechanism of seed drills, and transportation, separating and sizing systems (Nciri et al., 2014); bean varieties with large seeds exhibit slower water uptake and longer cooking time than small seeded varieties (Van Loggerenberg, 2004). Seed size influences electrical conductivity tests during soaking (Basra, 2006). Surface area plays a vital role in heat and mass transfer processes such as drying and other thermal applications. The surface area of an agricultural product is generally indicative of its pattern of behaviour in a flowing fluid such as air, as well as the ease of separating extraneous materials from the product during cleaning by pneumatic means (Omobuwajo, et al., 1999). The coefficient of determination $\left(\mathrm{R}^{2}\right)$ and correlation $(\mathrm{r})$ values obtained from the regression relationship between the dimensional properties and maturity stage for the three bean varieties, signified that any dimensional properties investigated can be predicted at any specific maturity stage.

Table 2: ANOVA of effect of maturity stage and variety on the dimensional properties of bean seeds

\begin{tabular}{|c|c|c|c|c|c|c|c|c|c|}
\hline Source & df & Length & & Width & & Thickness & & Dg & \\
\hline & & $\mathbf{F}$ & Sig & $\mathbf{F}$ & Sig & $\mathbf{F}$ & Sig & $\mathbf{F}$ & Sig \\
\hline $\mathrm{M}$ & 2 & 219.09 & $\begin{array}{l}2.04 \mathrm{E}- \\
17 *\end{array}$ & 176.88 & $\begin{array}{l}3.05 \mathrm{E}- \\
16^{*}\end{array}$ & 190.34 & $\begin{array}{l}1.21 \mathrm{E}- \\
16^{*}\end{array}$ & 304.94 & $\begin{array}{l}2.94 \mathrm{E}- \\
19 *\end{array}$ \\
\hline $\mathrm{V}$ & 2 & 31.50 & $\begin{array}{l}8.74 \mathrm{E}- \\
08 *\end{array}$ & 13.49 & $\begin{array}{l}8.68 \mathrm{E}- \\
05^{*}\end{array}$ & 33.70 & $\begin{array}{l}4.58 \mathrm{E}- \\
08^{*}\end{array}$ & 39.25 & $\begin{array}{l}1.02 \mathrm{E}- \\
08^{*}\end{array}$ \\
\hline$M \times V$ & 4 & 0.218 & $\begin{array}{l}0.9261 \\
\mathrm{~ns}\end{array}$ & 3.468 & $0.0207 *$ & 0.722 & $\begin{array}{l}0.5847 \\
\text { ns }\end{array}$ & 1.467 & $\begin{array}{l}0.2396 \\
\text { ns }\end{array}$ \\
\hline
\end{tabular}

$*$ Significant at $\mathrm{P} \leq 0.05, \mathrm{~ns}=$ non-significant, $\mathrm{M}=$ Maturity stage, $\mathrm{V}=$ bean variety,

Table 2: continued:

\begin{tabular}{|l|l|l|l|l|l|l|l|l|l|}
\hline Source & df & Da & \multicolumn{2}{l|}{ Sphericity } & Area & & Volume & \\
\hline & & F & Sig & F & Sig & F & Sig & F & Sig \\
\hline M & 2 & 301.26 & $\begin{array}{l}3.44 \mathrm{E}- \\
19^{*}\end{array}$ & 29.59 & $\begin{array}{l}1.56 \mathrm{E}- \\
07^{*}\end{array}$ & 281.41 & $\begin{array}{l}8.29 \mathrm{E}- \\
1 *^{*}\end{array}$ & 237.22 & $\begin{array}{l}7.42 \mathrm{E}- \\
18^{*}\end{array}$ \\
\hline $\mathrm{V}$ & 2 & 37.93 & $\begin{array}{l}1.44 \mathrm{E}- \\
08^{*}\end{array}$ & 2.03 & $0.15085^{\text {ns }}$ & 39.54 & $\begin{array}{l}9.49 \mathrm{E}- \\
09^{*}\end{array}$ & 37.00 & $\begin{array}{l}1.84 \mathrm{E}- \\
08^{*}\end{array}$ \\
\hline M x V & 4 & 1.323 & $0.2867^{\mathrm{ns}}$ & 3.012 & $0.0355^{*}$ & 2.751 & $0.0486^{*}$ & 4.316 & $0.0079^{*}$ \\
\hline
\end{tabular}

$*=$ Significant at $\mathrm{P} \leq 0.05, \mathrm{~ns}=$ non-significant, $\mathrm{M}=$ Maturity stage, $\mathrm{V}=$ bean variety,

Table 3: Dimensional properties of bean seeds at different maturity stage

\begin{tabular}{|l|l|l|l|l|}
\hline Parameter & Variety & \multicolumn{4}{l|}{ Maturity stage (DAF) } \\
\hline & & 15 & 20 & 25 \\
\hline Length & White & $8.40^{\mathrm{b}} \pm 0.48$ & $10.58^{\mathrm{a}} \pm 0.33$ & $12.15^{\mathrm{a}} \pm 0.49$ \\
\hline & Butter & $7.0^{\mathrm{b}} \pm 0.29$ & $9.98^{\mathrm{a}} \pm 0.46$ & $10.93^{\mathrm{a}} \pm 0.30$ \\
\hline & Brown & $7.45^{\mathrm{b}} \pm 0.42$ & $10.31^{\mathrm{a}} \pm 0.39$ & $11.26^{\mathrm{a}} \pm 0.72$ \\
\hline Width & White & $5.35^{\mathrm{a}} \pm 0.44$ & $7.65^{\mathrm{b}} \pm 0.31$ & $9.18^{\mathrm{c}} \pm 0.46$ \\
\hline & Butter & $5.18^{\mathrm{a}} \pm 0.17$ & $7.20^{\mathrm{b}} \pm 0.29$ & $8.15^{\mathrm{c}} \pm 0.13$ \\
\hline
\end{tabular}




\begin{tabular}{|l|l|l|l|l|}
\hline & Brown & $5.48^{\mathrm{a}} \pm 0.61$ & $7.33^{\mathrm{b}} \pm 0.59$ & $8.28^{\mathrm{c}} \pm 0.46$ \\
\hline Thickness & White & $4.10^{\mathrm{c}} \pm 0.22$ & $5.95^{\mathrm{b}} \pm 0.81$ & $7.30^{\mathrm{a}} \pm 0.22$ \\
\hline & Butter & $3.18^{\mathrm{c}} \pm 0.25$ & $5.4^{\mathrm{b}} \pm 0.30$ & $6.10^{\mathrm{a}} \pm 0.32$ \\
\hline & Brown & $3.45^{\mathrm{c}} \pm 0.24$ & $5.68^{\mathrm{b}} \pm 0.15$ & $6.33^{\mathrm{a}} \pm 0.44$ \\
\hline Geometric mean & White & $5.69^{\mathrm{c}} \pm 0.33$ & $7.83^{\mathrm{b}} \pm 0.46$ & $9.34^{\mathrm{a}} \pm 0.36$ \\
\hline & Butter & $4.86^{\mathrm{c}} \pm 0.21$ & $7.27^{\mathrm{b}} \pm 0.30$ & $8.16^{\mathrm{a}} \pm 0.18$ \\
\hline & Brown & $5.20^{\mathrm{c}} \pm 0.40$ & $7.54^{\mathrm{b}} \pm 0.31$ & $8.38^{\mathrm{a}} \pm 0.37$ \\
\hline Arithmetic mean & White & $5.95^{\mathrm{a}} \pm 0.35$ & $8.06^{\mathrm{b}} \pm 0.39$ & $9.54^{\mathrm{c}} \pm 0.37$ \\
\hline & Butter & $5.12^{\mathrm{a}} \pm 0.20$ & $7.53^{\mathrm{b}} \pm 0.31$ & $8.39^{\mathrm{c}} \pm 0.16$ \\
\hline Sphericity & Brown & $5.46^{\mathrm{a}} \pm 0.41$ & $7.78^{\mathrm{b}} \pm 0.33$ & $8.62^{\mathrm{c}} \pm 0.38$ \\
\hline & White & $67.72^{\mathrm{a}} \pm 0.73$ & $74.03^{\mathrm{b}} \pm 4.11$ & $76.85^{\mathrm{c}} \pm 0.98$ \\
\hline & Butter & $69.44^{\mathrm{a}} \pm 0.48$ & $73.08^{\mathrm{b}} \pm 1.32$ & $74.69^{\mathrm{c}} \pm 1.99$ \\
\hline Surface area & Brown & $69.75^{\mathrm{a}} \pm 2.24$ & $73.12^{\mathrm{b}} \pm 1.28$ & $74.51^{\mathrm{c}} \pm 2.50$ \\
\hline & White & $101.94^{\mathrm{a}} \pm 11.63$ & $193.00^{\mathrm{b}} \pm 23.02$ & $274.12^{\mathrm{c}} \pm 21.02$ \\
\hline & Butter & $74.34^{\mathrm{a}} \pm 6.32$ & $167.15^{\mathrm{b}} \pm 11.66$ & $209.11^{\mathrm{c}} \pm 8.89$ \\
\hline Volume & Brown & $85.33^{\mathrm{a}} \pm 13.06$ & $178.79^{\mathrm{b}} \pm 13.67$ & $221.01^{\mathrm{c}} \pm 19.32$ \\
\hline & White & $97.13^{\mathrm{c}} \pm 16.13$ & $253.10^{\mathrm{b}} \pm 45.38$ & $427.44^{\mathrm{a}} \pm 49.51$ \\
\hline & Butter & $60.40^{\mathrm{c}} \pm 7.67$ & $203.19^{\mathrm{b}} \pm 18.08$ & $284.47^{\mathrm{a}} \pm 18.09$ \\
\hline & Brown & $74.60^{\mathrm{c}} \pm 17.02$ & $224.78^{\mathrm{b}} \pm 23.97$ & $309.60^{\mathrm{a}} \pm 40.21$ \\
\hline
\end{tabular}

Values are mean \pm Standard Deviation; Means with similar superscript in the same row did not differ significantly $(\mathrm{p} \leq 0.05)$.

Table 4: Regression equations as a function of maturity stage with their respective coefficient of determination $\left(\mathrm{R}^{2}\right)$ and correlation $(\mathrm{r})$ values for dimensional properties of the bean seeds

\begin{tabular}{|l|l|l|l|l|}
\hline Parameter & Bean variety & Linear equation & $\mathbf{R}^{\mathbf{2}}$ & $\mathbf{r}$ \\
\hline Length & White & $\mathrm{y}=1.875 \mathrm{x}+6.6267$ & 0.991 & 0.995 \\
\hline & Butter & $\mathrm{y}=1.965 \mathrm{x}+5.3733$ & 0.918 & 0.958 \\
\hline & Brown & $\mathrm{y}=1.905 \mathrm{x}+5.5533$ & 0.999 & 0.960 \\
\hline Width & White & $\mathrm{y}=1.915 \mathrm{x}+3.5633$ & 0.986 & 0.993 \\
\hline & Butter & $\mathrm{y}=1.485 \mathrm{x}+3.54$ & 0.968 & 0.979 \\
\hline & Brown & $\mathrm{y}=1.4 \mathrm{x}+4.1967$ & 0.979 & 0.983 \\
\hline Thickness & White & $\mathrm{y}=1.915 \mathrm{x}+3.5633$ & 0.986 & 0.995 \\
\hline & Butter & $\mathrm{y}=1.46 \mathrm{x}+1.65$ & 0.993 & 0.957 \\
\hline & Brown & $\mathrm{y}=1.44 \mathrm{x}+2.2733$ & 0.908 & 0.953 \\
\hline Geometric mean & White & $\mathrm{y}=1.915 \mathrm{x}+3.5633$ & 0.986 & 0.995 \\
\hline & Butter & $\mathrm{y}=1.65 \mathrm{x}+3.13$ & 0.993 & 0.966 \\
\hline & Brown & $\mathrm{y}=1.59 \mathrm{x}+3.86$ & 0.931 & 0.941 \\
\hline Arithmetic mean & White & $\mathrm{y}=1.915 \mathrm{x}+3.5633$ & 0.987 & 0.994 \\
\hline & Butter & $\mathrm{y}=1.635 \mathrm{x}+3.41$ & 0.993 & 0.964 \\
\hline & Brown & $\mathrm{y}=1.58 \mathrm{x}+4.12$ & 0.935 & 0.965 \\
\hline Sphericity & White & $\mathrm{y}=4.565 \mathrm{x}+63.737$ & 0.954 & 0.977 \\
\hline & Butter & $\mathrm{y}=2.625 \mathrm{x}+67.153$ & 0.952 & 0.976 \\
\hline & Brown & $\mathrm{y}=2.38 \mathrm{x}+67.893$ & 0.873 & 0.934 \\
\hline Surface area & White & $\mathrm{y}=86.09 \mathrm{x}+17.507$ & 0.998 & 0.999 \\
\hline & Butter & $\mathrm{y}=67.385 \mathrm{x}+15.43$ & 0.954 & 0.912 \\
\hline
\end{tabular}




\begin{tabular}{|l|l|l|l|l|}
\hline & Brown & $\mathrm{y}=67.84 \mathrm{x}+26.03$ & 0.954 & 0.977 \\
\hline Volume & White & $\mathrm{y}=86.09 \mathrm{x}+17.507$ & 0.998 & 0.999 \\
\hline & Butter & $\mathrm{y}=112.04 \mathrm{x}-41.383$ & 0.975 & 0.987 \\
\hline & Brown & $\mathrm{y}=117.5 \mathrm{x}-32.007$ & 0.974 & 0.987 \\
\hline
\end{tabular}

\subsection{Gravimetric Properties}

In reference to the ANOVA table (Table 5), maturity stage had significant ( $\mathrm{p}<0.05)$ effect on all the gravimetric properties of the three bean varieties. The regression equations of maturity stage as a function of gravimetric properties of bean seeds with their respective coefficient of determination $\left(\mathrm{R}^{2}\right)$ and correlation (r) values given in Table 6 , shows a strong relationship between maturity stage of the bean seeds and the gravimetric properties investigated in this research. The section below discusses how maturity stage influenced the gravimetric properties of the three bean varieties seeds.

Table 5: The ANOVA of effect of maturity stage and variety on the gravimetric properties of bean seeds

\begin{tabular}{|l|l|l|l|l|l|l|l|l|l|}
\hline Source & df & $\mathbf{1 0 0 0}$ & & Bulk & & True & & Porosity & \\
\hline & & F & Sig & F & Sig & F & Sig & F & Sig \\
\hline M & 2 & 114.05 & $\begin{array}{l}6.79 \mathrm{E}- \\
14^{*}\end{array}$ & 15725 & $\begin{array}{l}3.98 \mathrm{E}- \\
42^{*}\end{array}$ & 24922 & $\begin{array}{l}7.98 \mathrm{E}- \\
45^{*}\end{array}$ & 918 & $\begin{array}{l}1.48 \mathrm{E}- \\
25^{*}\end{array}$ \\
\hline $\mathrm{V}$ & 2 & 27.285 & $\begin{array}{l}3.29 \mathrm{E}- \\
07^{*}\end{array}$ & 447 & $\begin{array}{l}2.02 \mathrm{E}- \\
21^{*}\end{array}$ & 1949 & $\begin{array}{l}6.41 \mathrm{E}- \\
30^{*}\end{array}$ & 72 & $\begin{array}{l}1.42 \mathrm{E}- \\
11^{*}\end{array}$ \\
\hline M x V & 4 & 1.2207 & $\begin{array}{lll}0.3252 \\
\text { n }\end{array}$ & 15 & $\begin{array}{l}1.27 \mathrm{E}- \\
06^{*}\end{array}$ & 11 & $\begin{array}{l}2.28 \mathrm{E}- \\
05^{*}\end{array}$ & 12 & $\begin{array}{l}3.03 \mathrm{E}- \\
08^{*}\end{array}$ \\
\hline
\end{tabular}

$*=$ Significant at $\mathrm{P} \leq 0.05, \mathrm{~ns}=$ non-significant, $\mathrm{M}=$ Maturity stage, $\mathrm{V}=$ bean variety,

Table 6: Regression equations of the gravimetric properties as a function of maturity stage with their respective coefficient of determination $\left(\mathrm{R}^{2}\right)$ and correlation $(\mathrm{r})$ values

\begin{tabular}{|l|l|l|l|l|}
\hline Parameter & Bean variety & Regression equation & $\mathbf{R}^{2}$ & $\mathbf{r}$ \\
\hline 1000 seed mass & White & $\mathrm{y}=76.75 \mathrm{x}+156.42$ & 0.945 & 0.992 \\
\hline & Butter & $\mathrm{y}=61.5 \mathrm{x}+141.5$ & 0.909 & 0.953 \\
\hline & Brown & $\mathrm{y}=76 \mathrm{x}+165.42$ & 0.964 & 0.982 \\
\hline Bulk density & White & $\mathrm{y}=157.38 \mathrm{x}+376.17$ & 0.973 & 0.986 \\
\hline & Butter & $\mathrm{y}=144.13 \mathrm{x}+454.5$ & 0.943 & 0.971 \\
\hline & Brown & $\mathrm{y}=152.63 \mathrm{x}+407.83$ & 0.969 & 0.985 \\
\hline True density & White & $\mathrm{y}=176.75 \mathrm{x}+703.17$ & 0.925 & 0.962 \\
\hline & Butter & $\mathrm{y}=180.5 \mathrm{x}+789.83$ & 0.930 & 0.964 \\
\hline & Brown & $\mathrm{y}=167.75 \mathrm{x}+734.75$ & 0.918 & 0.957 \\
\hline Porosity & White & $\mathrm{y}=-4.125 \mathrm{x}+43.317$ & 0.997 & -0.998 \\
\hline & Butter & $\mathrm{y}=-2.555 \mathrm{x}+40.853$ & 0.959 & -0.979 \\
\hline & Brown & $\mathrm{y}=-3.965 \mathrm{x}+41.713$ & 0.997 & -0.998 \\
\hline
\end{tabular}

\section{Thousand Seed Mass}

The thousand seed mass differed significantly $(\mathrm{P}<0.05)$ among the various bean varieties. Referring to Figure 2, it can be seen that Brown bean seeds had the highest thousand seed mass at 
25 DAF (385.00 $\pm 14.26 \mathrm{~g})$, while butter bean seeds had the lowest highest thousand seed mass at 25 DAF (314.75 $\pm 12.31 \mathrm{~g})$. In addition, there was not much changes in the mass of the three bean varieties, between $20 \mathrm{DAF}$ and $25 \mathrm{DAF}$, signifying that the beans seeds attain full maturity as from 20 DAF. Thousand seeds mass is an important parameter in the design bean storage facility (capacity) and machinery design. Therefore, the size data of beans is of mostly importance to Agrofood engineers, machine manufacturers, and machine designers (Kara et al., 2013). Gathu et al., (2012) reported the 100-seed mass values of eight bean lines (Phaseolus vulgaris) varied from 15.77 to $36.90 \mathrm{~g} / 100$ seeds; while Borji et al., (2007), studied the seed mass of 10 genotypes of dry bean, and found the averages weight values to be in the range of 23.20-38.43 g/ 100 seeds. Harvesting crops at early maturity stage usually resulted in yield loss due to high seed moisture content, high percentage of immature seeds and low 1000 seed weight; while delayed harvesting resulted in more seeds were filled and consequently, average seed weight increased (Siddique and Wright, 2003; Nimje and Gandhi, 1994).

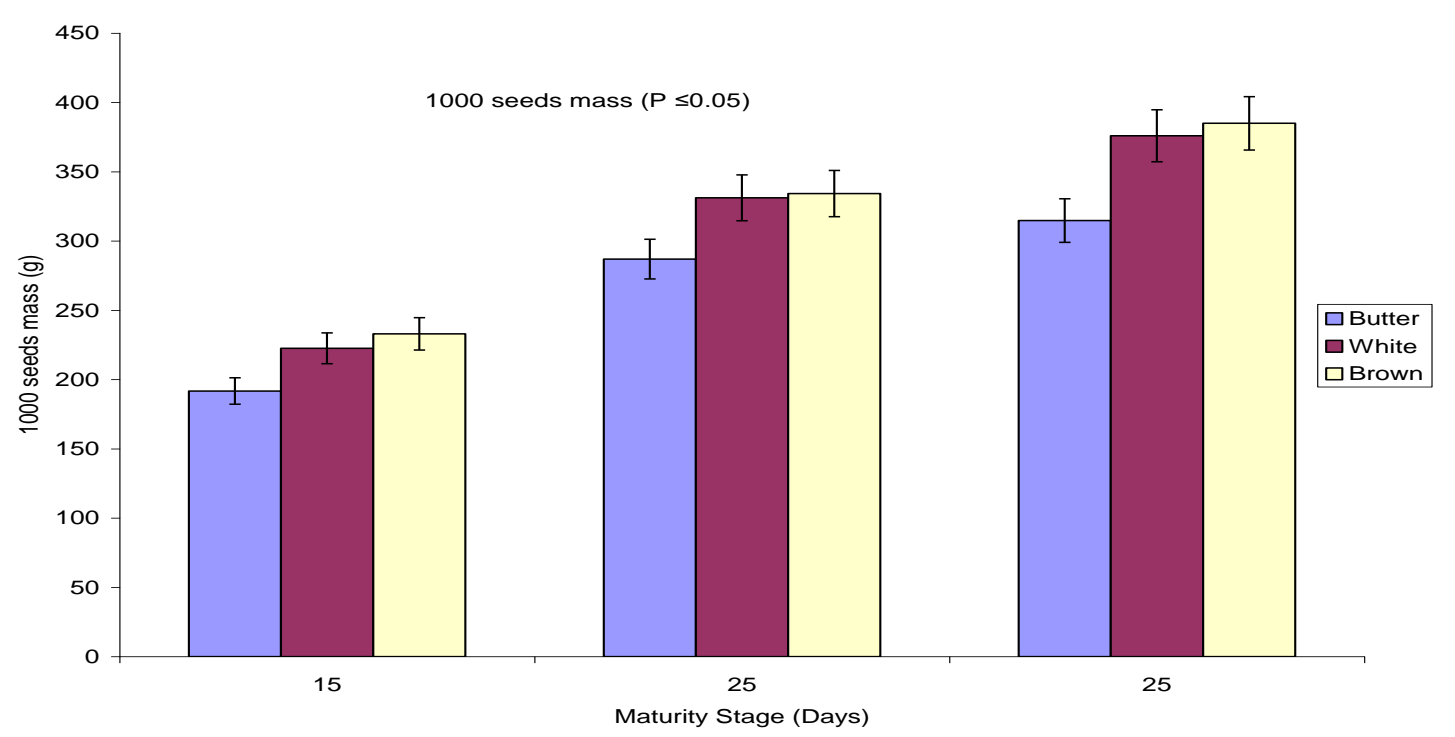

Figure 2: Influence maturity stage on bean seed 1000 seed mass

\section{Bean Seeds Bulk and True Density}

Examining Figure 3, it can be seen that the bean seeds bulk and true density increased with increase in maturation of the bean seeds. From the figure, Butter bean seeds had the highest density values, while white bean seeds had the lowest density values. The true density of dry bean seeds at 20 and $25 \mathrm{DAF}$ were higher than $1000 \mathrm{~kg} / \mathrm{m}^{3}$, indicating that the seeds are heavier than water and hence sink. This can be attributed to the change of the bean textural and material structures as the seed matures. Longer photoperiods may also result in greater production of phtosynthates and to increase biomass, growth efficiency, duration of crop and yield per plant and thus mitigating source limitations (Indira and Dharmalingam, 1996; Summerfield et al., 1988; Ellis et al., 2000). During initial maturation stage, despite with the high moisture content, the seeds of the two bean varieties have lower bulk density, which increased proportionally during the maturation course. This tendency was probably due to the gradual change in the integrity of the cellular matrix (Gupta and Das, 2000). The true density indicates that the seeds at full maturity are heavier than water; while premature seeds are lighter than water; this characteristic can be used to design separation or cleaning process (Mpotokwane et al., 2008). 
Density of food materials and agricultural products play an important role in the design of silos and storage bins (Waziri and Mittal, 1983); determining the purity of seeds (Jaeger, 1997); stability of feed pellet and wafers (Gustustafson and Kjelgard, 2000); mechanical compressing of ensilages (Ige, 1997) and maturity evaluation (Fashina,1996). Since the true density of the mature bean seeds is more than the density of water, water can be used to design separation or cleaning processes for the bean seeds since premature bean seeds (lighter than water density) will float on top of the water. In related development, bulk density and true density can be useful in sizing grain hoppers and storage facilities; seeds and grain densities have been of interest in breakage susceptibility and hardness studies (Heidarbeigi et al, 2009). (Shimelis and Rakshit, 2005), studied the physical properties of eight improved bean varieties namely: 'Roba', 'Mexican', 'Red wolayita', 'Awash', 'Gofta', 'Beshbesh', 'Gobirasha', and 'Tabor'. And found that the density of varieties varied from 1.177 to $1.343 \mathrm{~g} / \mathrm{mL}$.

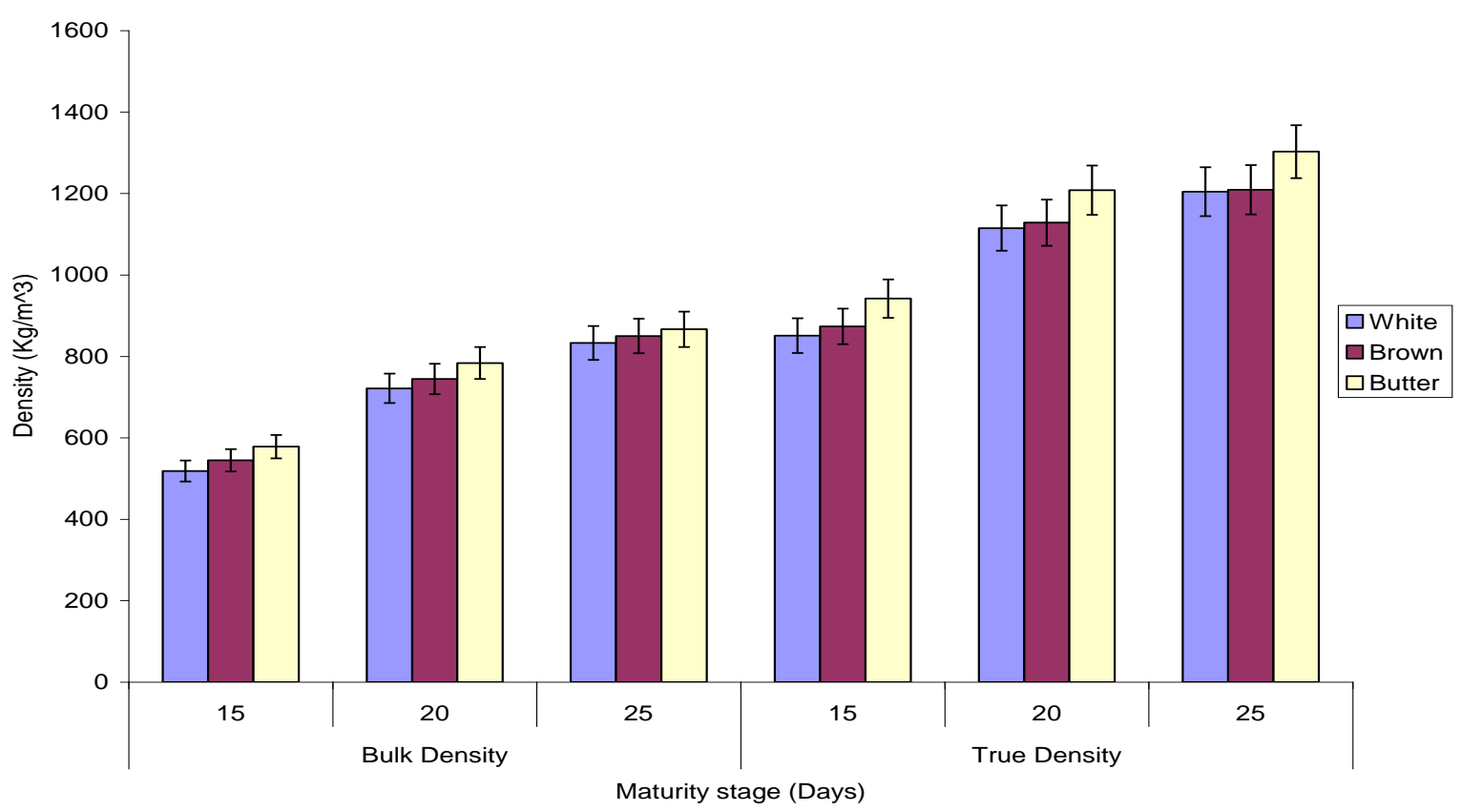

Figure 3: Influence maturity stage on bean seeds bulk and true density

\section{Porosity}

The porosity of the three bean varieties decreases with increased in maturation of the bean seeds (Figure 4). In reference to the ANOVA table, maturity stage had a significant effect on the porosity of both bean varieties. Porosity is the fraction of the space in the bulk seeds which is not occupied by the seeds (Coşkuner and Karababa, 2007), and depends on the geometry and surface properties of the material (Mpotokwane et al., 2008) which allow fluid to pass through the bulk. It is useful in the calculation of the rate of aeration and cooling, drying and heating and in the design of heat exchangers and other similar equipment for bean handling (Asoegwu et al., 2006). Porosity has practical applications in the design of aeration systems during storage. It is also needed by the design engineer to know the number of seeds that will enter a hollow seed tube of the planter (Akaaimo \& Raji, 2006). Seeds with low porosity dry very slowly, therefore, drying the bean seeds through natural aeration will be difficult. 


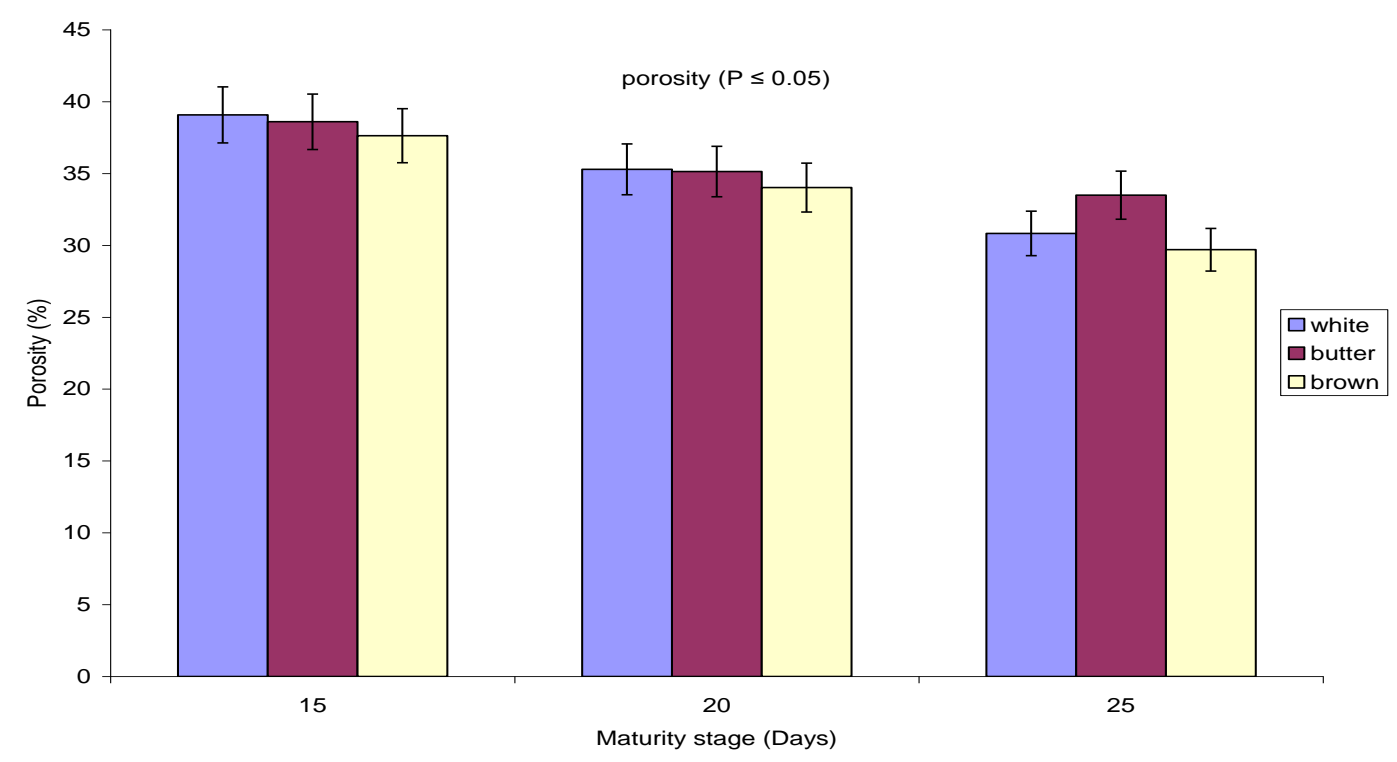

Figure 4: Influence maturity stage on bean seeds porosity

\subsection{Functional Properties}

\section{Hydration, Swelling Capacities and Their Coefficients}

As shown in the ANOVA table (Table 6), significant differences $(\mathrm{P}<0.05)$ occurred in the hydration and swelling capacities as well as the hydration and swelling coefficients, during their maturation period. Table 7 illustrates the hydration and swelling capacities, with the respective coefficients of the three bean varieties; and how their behaviour with increased in maturation. From the results of the study, the value of swelling coefficient was highest in butter beans, probably due to its textural structure making to swell faster than the other two bean varieties. Hydration and swelling capacities of the three bean varieties increases with increased in maturation of the seeds (from 15 DAF to 25 DAF); Butter bean seeds possessed the highest swelling capacity among the three bean varieties, while Brown bean seeds had the lowest value (Table 7). The high value of swelling coefficient of butter bean seeds among the three bean varieties beans seeds revealed their high swelling ability.

Table 6: The ANOVA of effect of maturity stage and variety on the functional properties of bean seeds

\begin{tabular}{|l|l|l|l|l|l|l|l|l|l|}
\hline Source & df & \multicolumn{2}{l|}{$\begin{array}{l}\text { Hydration } \\
\text { capacity }\end{array}$} & \multicolumn{2}{l|}{ Swelling capacity } & \multicolumn{2}{l|}{$\begin{array}{l}\text { Hydration } \\
\text { coefficient }\end{array}$} & \multicolumn{2}{l|}{$\begin{array}{l}\text { Swelling } \\
\text { coefficient }\end{array}$} \\
\hline & & F & Sig & F & Sig & F & Sig & F & Sig \\
\hline M & 2 & 896.39 & $\begin{array}{l}2.06 \mathrm{E}- \\
25^{*}\end{array}$ & 901.85 & $\begin{array}{l}1.89 \mathrm{E}- \\
25^{*}\end{array}$ & 679.72 & $\begin{array}{l}8.09 \mathrm{E}- \\
24^{*}\end{array}$ & 679.75 & $\begin{array}{l}8.08 \mathrm{E}- \\
24^{*}\end{array}$ \\
\hline $\mathrm{V}$ & 2 & 167.55 & $\begin{array}{l}6.02 \mathrm{E}- \\
16^{*}\end{array}$ & 44.27 & $\begin{array}{l}2.99 \mathrm{E}- \\
09^{*}\end{array}$ & 366.35 & $\begin{array}{l}2.72 \mathrm{E}- \\
20^{*}\end{array}$ & 409.13 & $\begin{array}{l}6.44 \mathrm{E}- \\
21^{*}\end{array}$ \\
\hline M x V & 4 & 1.40 & 0.260217 & 2.02 & 0.119544 & 23.56 & $\begin{array}{l}1.79 \mathrm{E}- \\
08^{*}\end{array}$ & 15.83 & $\begin{array}{l}8.69 \mathrm{E}- \\
07^{*}\end{array}$ \\
\hline
\end{tabular}

* =Significant at $\mathrm{P} \leq 0.05, \mathrm{~ns}=$ non-significant, $\mathrm{M}=$ Maturity stage, $\mathrm{V}=$ bean variety, 
These differences in the functional properties of the three bean varieties may be attributed to their difference in size, seed coat thickness, and water absorption characteristics of seeds (Sefa-Dedah et al., 1979). Swelling ability of any seed depends upon its water retention capacity. The hydration and swelling coefficients reflect the capacity to absorb water in a reasonable length of soaking (Nciri et al., 2014; Nasar-Abbas et al., 2008). Hydration and swelling capacities of bean seeds are useful parameters to the food processing industry; for instance, larger hydration capacity leads to better cooking quality while swelling capacity helps in dehusking of the pods. Since large hydration coefficient leads to better cooking texture and cooking time, (Teshome and Emire, 2012); butter bean seeds would require lesser fuel and energy to be cooked. The results of this study are consistent with the research findings presented by (Shimelis and Rakshit, 2005; Buzera, et al. 2018; Nciri et al., 2014), who reported wide variation in hydration and swelling coefficient across of beans varieties. (Akromah et al., 2015) noted that the swelling volume is desirable characteristic that influences acceptability of beans since high grain expansion during cooking is preferred.

Table 7: Functional properties of the three bean varieties

\begin{tabular}{|l|l|l|l|l|}
\hline Parameter & Variety & \multicolumn{4}{l}{ Maturity stage (DAF) } \\
\hline & & $\mathbf{1 5}$ & $\mathbf{2 0}$ & $\mathbf{2 5}$ \\
\hline Hydration capacity (g/seed) & White & $0.183^{\mathrm{a}} \pm 0.010$ & $0.333^{\mathrm{b}} \pm 0.010$ & $0.400^{\mathrm{c}} \pm 0.018$ \\
\cline { 2 - 5 } & Butter & $0.165^{\mathrm{a}} \pm 0.013$ & $0.308^{\mathrm{b}} \pm 0.019$ & $0.385^{\mathrm{c}} \pm 0.006$ \\
\hline & Brown & $0.108^{\mathrm{a}} \pm 0.013$ & $0.240^{\mathrm{b}} \pm 0.008$ & $0.303^{\mathrm{c}} \pm 0.010$ \\
\hline Swelling capacity (vol/seed) & White & $0.343^{\mathrm{c}} \pm 0.013$ & $0.523^{\mathrm{b}} \pm 0.030$ & $0.680^{\mathrm{a}} \pm 0.022$ \\
\cline { 2 - 5 } & Butter & $0.425^{\mathrm{c}} \pm 0.013$ & $0.723^{\mathrm{b}} \pm 0.017$ & $0.840^{\mathrm{a}} \pm 0.026$ \\
\hline & Brown & $0.298^{\mathrm{c}} \pm 0.022$ & $0.435^{\mathrm{b}} \pm 0.021$ & $0.513^{\mathrm{a}} \pm 0.025$ \\
\hline \multirow{2}{*}{ Hydration coefficient (\%) } & White & $1.235^{\mathrm{a}} \pm 0.026$ & $1.815^{\mathrm{b}} \pm 0.068$ & $2.113^{\mathrm{c}} \pm 0.059$ \\
\cline { 2 - 5 } & Butter & $1.320^{\mathrm{a}} \pm 0.026$ & $1.850^{\mathrm{b}} \pm 0.045$ & $2.280^{\mathrm{c}} \pm 0.029$ \\
\hline & Brown & $1.153^{\mathrm{a}} \pm 0.013$ & $1.680^{\mathrm{b}} \pm 0.104$ & $2.015^{\mathrm{c}} \pm 0.037$ \\
\hline Swelling coefficient (\%) & White & $1.330^{\mathrm{c}} \pm 0.016$ & $2.193^{\mathrm{b}} \pm 0.059$ & $2.363^{\mathrm{a}} \pm 0.087$ \\
\hline & Butter & $1.933^{\mathrm{c}} \pm 0.135$ & $3.158^{\mathrm{b}} \pm 0.054$ & $3.525^{\mathrm{a}} \pm 0.170$ \\
\hline & Brown & $1.445^{\mathrm{c}} \pm 0.026$ & $2.165^{\mathrm{b}} \pm 0.061$ & $2.543^{\mathrm{a}} \pm 0.022$ \\
\hline
\end{tabular}

Values are mean \pm Standard Deviation; Means with similar superscript in the same row did not differ significantly $(\mathrm{p} \leq 0.05)$.

The regression equations of maturity stage as a function of functional properties of bean seeds with their respective coefficient of determination $\left(\mathrm{R}^{2}\right)$ and correlation $(\mathrm{r})$ values given in Table 8 , shows a strong relationship between maturity stage of the bean seeds and the functional properties investigated in this research

Table 8: Regression equations of the functional properties as a function of maturity stage with their respective coefficient of determination $\left(\mathrm{R}^{2}\right)$ and correlation $(\mathrm{r})$ values

\begin{tabular}{|l|l|l|l|l|}
\hline Parameter & Bean variety & Regression equation & $\mathbf{R}^{\mathbf{2}}$ & $\mathbf{r}$ \\
\hline Hydration capacity $(\mathrm{g} / \mathrm{seed})$ & White & $\mathrm{y}=0.1085 \mathrm{x}+0.0883$ & 0.954 & 0.976 \\
\hline & Butter & $\mathrm{y}=0.11 \mathrm{x}+0.066$ & 0.971 & 0.985 \\
\hline & Brown & $\mathrm{y}=0.0975 \mathrm{x}+0.022$ & 0.959 & 0.979 \\
\hline Swelling capacity (vol/seed) & White & $\mathrm{y}=0.1685 \mathrm{x}+0.1783$ & 0.998 & 0.999 \\
\hline & Butter & $\mathrm{y}=0.2075 \mathrm{x}+0.2477$ & 0.940 & 0.969 \\
\hline
\end{tabular}




\begin{tabular}{|l|l|l|l|l|}
\hline & Brown & $\mathrm{y}=0.1075 \mathrm{x}+0.2003$ & 0.975 & 0.987 \\
\hline Hydration coefficient (\%) & White & $\mathrm{y}=0.439 \mathrm{x}+0.843$ & 0.967 & 0.983 \\
\hline & Butter & $\mathrm{y}=0.48 \mathrm{x}+0.8567$ & 0.996 & 0.998 \\
\hline & Brown & $\mathrm{y}=0.431 \mathrm{x}+0.754$ & 0.983 & 0.992 \\
\hline Swelling coefficient $(\%)$ & White & $\mathrm{y}=0.5165 \mathrm{x}+0.929$ & 0.870 & 0.932 \\
\hline & Butter & $\mathrm{y}=0.796 \mathrm{x}+1.28$ & 0.912 & 0.954 \\
\hline & Brown & $\mathrm{y}=0.549 \mathrm{x}+0.953$ & 0.969 & 0.984 \\
\hline
\end{tabular}

\subsection{Frictional Properties}

\section{Coefficient of Static Friction}

The static friction of the bean seeds was significantly $(\mathrm{P} \leq 0.05)$ influenced by the maturity stage and variety of the bean seeds (Table 9). It was observed that the static coefficient of friction increased with increase in maturation for all the surfaces, which can be attributed to the changes in the shape and bulk density of the seeds as they matured. In reference to Figure 5, all the bean seeds harvested at $15 \mathrm{DAF}$, had poorer static friction when compared to those harvested at 25 DAF. Fictional properties of fruits, seeds and nuts are vital in the design of the storage containers, and for loading and unloading during handling (e.g. machine hopper). The angle of internal friction is required to calculate the lateral pressure which causes bending of the wall in storage bin as well as gravity flow in hoppers (Akaaimo and Raji, 2006). The coefficient of static friction was the lowest in the glass surface, this could be attributed to the smooth surface of the glass when compared to the other surfaces used. The coefficient of friction is an important parameter in selecting appropriate materials for different units of machinery, especially for components requiring flow of the seeds (Coşkuner and Gökbudak, 2016). The regression relationships between maturity stage and static coefficients of friction on all test surfaces are presented in Table 10.

Table 9: The ANOVA of effect of maturity stage and variety on the frictional properties of bean seeds

\begin{tabular}{|l|l|l|l|l|}
\hline Parameter & Source & df & F & Sig \\
\hline Coefficient of static friction & M & 2 & 956.86 & $4.45 \mathrm{E}-57^{*}$ \\
\cline { 2 - 5 } & V & 2 & 7779.19 & $2.678 \mathrm{E}-93^{*}$ \\
\cline { 2 - 5 } & S & 2 & 946.54 & $6.771 \mathrm{E}-57^{*}$ \\
\hline & M x V & 4 & 20.56 & $1 . \mathrm{E}-11^{*}$ \\
\hline & M x S & 4 & 1.74 & $0.150^{\text {ns }}$ \\
\hline & V x S & 4 & 34.19 & $1.06 \mathrm{E}-16^{*}$ \\
\hline & M x V x S & 8 & 1.08 & $0.382^{\text {ns }}$ \\
\hline Angle of repose & M & 2 & 288.308 & $6.06 \mathrm{E}-19^{*}$ \\
\hline & V & 2 & 174.68 & $3.57 \mathrm{E}-16^{*}$ \\
\hline & M x V & 4 & 2.1215 & $0.1056^{\text {ns }}$ \\
\hline
\end{tabular}

* = Significant at $\mathrm{P} \leq 0.05, \mathrm{~ns}=$ non-significant, $\mathrm{M}=$ Maturity stage, $\mathrm{V}=$ bean variety, $\mathrm{S}=$ surface of static friction 
Table 10: Regression equations of the frictional properties as a function of maturity stage with their respective coefficient of determination $\left(\mathrm{R}^{2}\right)$ and correlation $(\mathrm{r})$ values

\begin{tabular}{|l|l|l|l|l|l|}
\hline Parameter & Surface & Bean variety & Regression equation & $\mathbf{R}^{\mathbf{2}}$ & $\mathbf{r}$ \\
\hline Coefficient of static friction & Plywood & White & $\mathrm{y}=0.06 \mathrm{x}+0.5367$ & 0.964 & 0.982 \\
\cline { 2 - 6 } & & Butter & $\mathrm{y}=0.055 \mathrm{x}+0.39$ & 0.976 & 0.987 \\
\hline & & Brown & $\mathrm{y}=0.065 \mathrm{x}+0.48$ & 0.983 & 0.991 \\
\hline & laminate & White & $\mathrm{y}=0.06 \mathrm{x}+0.27$ & 0.923 & 0.960 \\
\hline & & Butter & $\mathrm{y}=0.045 \mathrm{x}+0.19$ & 0.964 & 0.981 \\
\hline & & Brown & $\mathrm{y}=0.06 \mathrm{x}+0.22$ & 0.923 & 0.961 \\
\hline & Glass & White & $\mathrm{y}=0.045 \mathrm{x}+0.15$ & 0.964 & 0.982 \\
\hline & & Butter & $\mathrm{y}=0.025 \mathrm{x}+0.1067$ & 0.987 & 0.993 \\
\hline & & Brown & $\mathrm{y}=0.035 \mathrm{x}+0.1433$ & 0.855 & 0.924 \\
\hline Angle of repose & & White & $\mathrm{y}=-4.335 \mathrm{x}+42.14$ & 0.972 & - \\
& & & & & 0.985 \\
\hline & & Butter & $\mathrm{y}=-4.105 \mathrm{x}+47.583$ & 0.988 & - \\
& & & & & 0.993 \\
\hline & & Brown & $\mathrm{y}=-3.405 \mathrm{x}+44.8$ & 0.998 & - \\
& & & & 0.999 \\
\hline
\end{tabular}

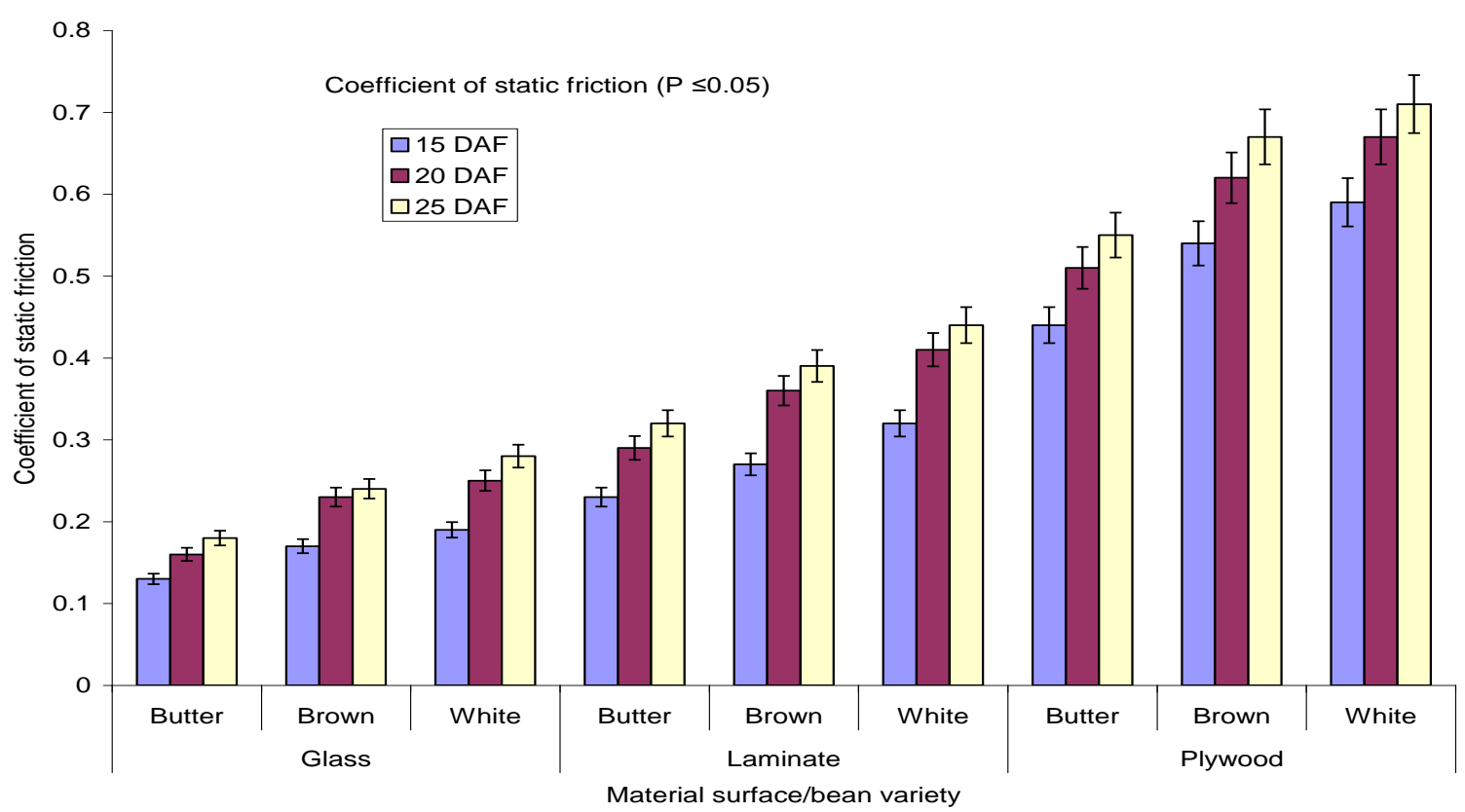

Figure 5: Influence maturity stage on bean seeds coefficient of static friction

\section{Angle of Repose}

From the ANOVA table (Table 9), bean variety and maturity stage had significant ( $p<0.05)$ effect on the angle of repose of the bean seeds. The angle of repose was higher for Butter bean seeds at all the maturity stages evaluated in this study, than the rest two bean variety. The decline in the angle of repose for both variety of beans as maturation progresses (Figure 6), could be attributed to the variation in the bean size and shape as maturation period progresses. In addition, moisture content of the seeds plays a vital role in the declining of the angle of response during maturation 
of the seeds. Gharibzahedi et al. (2010) reported that seeds might stick together at the higher moisture content, which results in less flowability and better stability, thereby increasing the angle of repose.

Angle of repose is importance in designing hopper openings, sidewall slopes of storage bins, chutes for bulk transporting of seeds and it is particularly useful for calculating the quantity of granular materials which can be placed implies or flat storages (Gharibzahedi et al., 2009); therefore, the maturity stage of bean seeds should be taken into account while designing processing and handling equipment. The increase of dynamic angle of repose was due to increase of internal friction with increase of contact surface area among the seeds, as any increase in internal friction among seeds will bring a resultant increase in the angle of repose of the seeds (Eze and Igwillo, 2018). The regression relationship existing between maturity stage and angle of repose is presented in Table10.

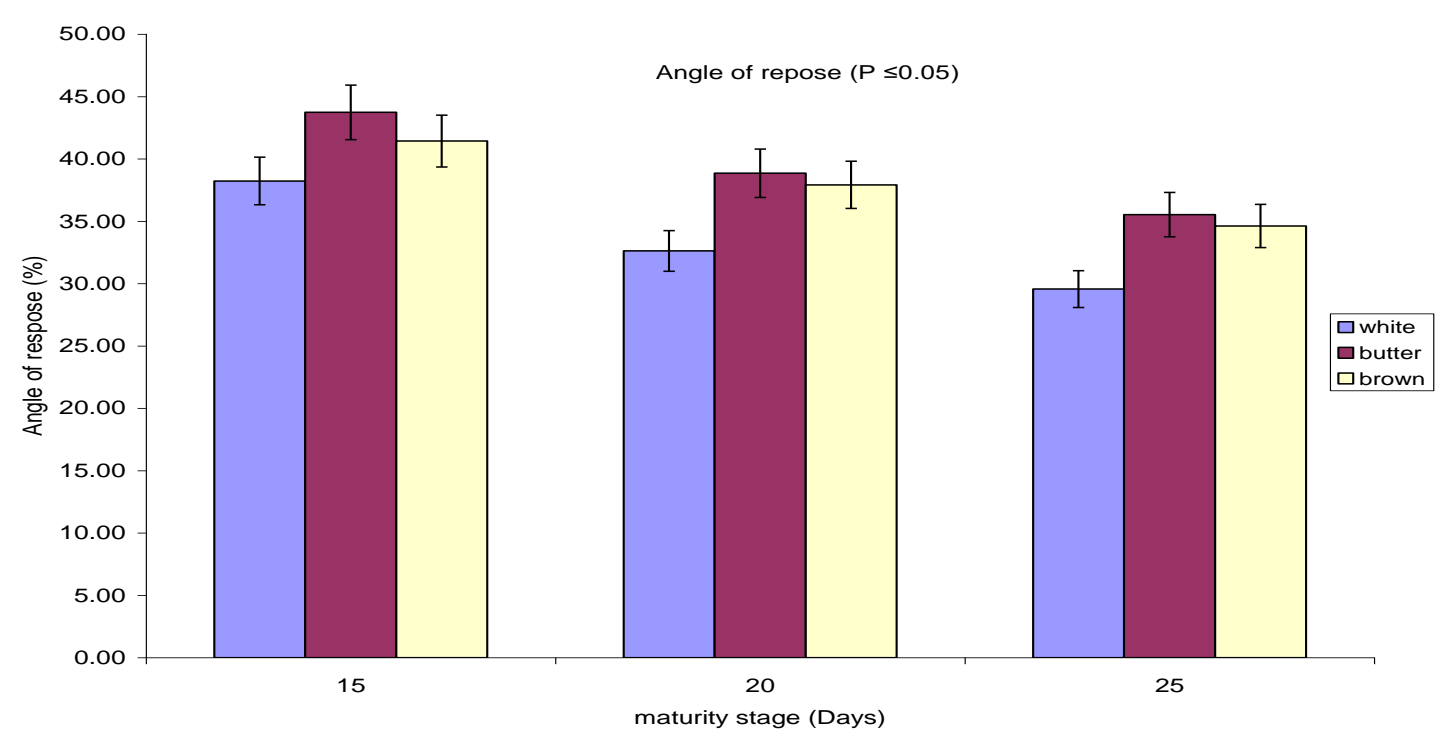

Figure 6: Influence maturity stage on bean seeds angle of response

\section{Conclusion}

This study provided basic information on engineering properties of three common bean (Phaseolus vulgaris L.) varieties namely: butter, brown and white cowpea. The engineering attributes including seed mass, moisture content, sphericity, geometric mean, arithmetic mean, volume, seed size, seed density, porosity, coefficient of static friction, hydration capacity, hydration coefficient, swelling capacity, and swelling coefficient were evaluated. The results maturity stage significantly $(\mathrm{P}<0.05)$ influences all the parameters investigated. Apart from the true density and angle of repose, all the other parameters increased linearly with increase in maturation of the bean seeds. In respect to the functional properties, Butter beans had the highest swelling capacity and coefficient. In addition, the moisture content of the bean seeds declined with maturity of the bean seeds, signifying increased in dry matter of the bean seeds as maturity progresses. Data gotten from this result will be useful in the design and development of harvesting, handling and processing equipment. 


\section{References}

[1] Agbogidi, O. M. and Egho, E.O. (2012). Evaluation of eight varieties of cowpea (Vigna unguiculata (L.) Walp) in Asaba agro-ecological environment, Delta State, Nigeria. European Journal of Sustainable Development (2012), 1, 2, 303-314

[2] Aghkhani, M. H., Ashtiani, S. H. M., and Motie, J. B. (2012). Physical properties of Christmas Lima bean at different moisture content. International Agrophysics, 26(1970), 341-346. https://doi.org/10.2478/v10247-012-0048-0

[3] Akaaimo, D. I. and Raji, A. O. (2006). Some physical and engineering properties of Prosopis africana seed. Biosystems Engineering, 95(2), 197-205.

[4] Akromah, R., Akpalu, M. M., Ninfaa, A. D., and Nyamah, E. Y. (2015). Participatory rural appraisal of constraints to groundnut (Arachis hypogaea L) Production in northern Ghana. International Journal of Current Research and Academic Review 3(10), 54-76.

[5] Altuntas, E., and Demirtola, H. (2007). Effect of moisture content on physical properties of some grain legume seeds. New Zealand Journal of Crop and Horticultural Science, 35(4), 423-433. https://doi.org/10.1080/01140670709510210

[6] AOAC (2000). Association of Official Analytical Chemists, Official Methods of Analysis. $16^{\text {th }}$ edition. Washington, DC.

[7] Asoegwu, S. N., Ohanyere, S. O., Kanu, O. P., and Iwueke, C. N. (2006). Physical Properties of African Oil Bean Seed (Pentaclethra macrophylla), Agricultural Engineering International: the CIGR Ejournal. Manuscript FP 05 006. Vol. VIII., 1-16.

[8] Ayenlere, A. E., Mohammed, A. B., Dutse, F., Abdullahi, M. and Mohammed-Lawal, A. (2012). An assessment of the economics of maize-cowpea cropping system in Ogun area of Kwara State, Nigeria Biological and Environmental Sciences Journal for the Tropics 9(1): 39-43

[9] Basra, A.S., (2006). Handbook of Seed Science and Technology. Haworth Press Inc., Binghamton, NY., ISBN: 1560223146, Pages: 625.

[10] Bedance, G. M., Gupta, M. L., George, D.L. (2006) Optimum harvest maturity for guayule seed. Industrial Crops Production. 24: 26-33

[11] Bishnoi, S. and Khetarpaul, N. (1993). Variability in physico-chemical properties and nutrient composition of different pea cultivars. Food Chemistry, 47(4): 371-373

[12] Borji, M., Ghorbanli, M. and Sarlak, M. (2007). Some seed traits and their relationships to seed germination, emergence rate electrical conductivity in common bean (Phaseolus vulgaris L.). Asian Journal of Plant Sciences, 6(5): 781-787

[13] Broughton, W.J., Hernandez, G., Blair, M., Beebe, S., Gepts, P. and Vanderleyden, J. (2003) Beans (Phaseolus spp.)-Model Food Legumes. Plant and Soil, 252, 55-128. http://dx.doi.org/10.1023/A:1024146710611

[14] Buzera, A.,Kinyanjui, P., Ishara, J. and Sila, D. (2018). Physical and cooking properties of two varieties of bio-fortified common beans (Phaseolus Vulgaris. L) grown in DR Congo. IISTE Food science and quality management 2224-6088. 71. 1-12.

[15] Carneiro, J.C.S., Minim, V.P.R, Souza Junior, M.M., Carneiro, J.E.S. and Araujo, G.A.A. (2005). Sensory profile and acceptability of bean cultivars (Phaseolus vulgaris L). Ciênc. Tecnol. Food. 25: $18-24$

[16] Coşkuner, Y., and Karababa, E. (2007). Some physical properties of flaxseed (Linum usitatissimum L.). Journal of Food Engineering, 78(3), 1067-1073. https://doi.org/10.1016/j.jfoodeng.2005.12.017

[17] Demir, I., and Ellis R.H. (1993). Changes in potential seed longevity and seedling growth during seed development and maturation in marrow (Cucurbita pepo L.). Seed Science Research 3: pp 247-257.

[18] Ellis, R. H. Asumadu H, Qi, A, Summerfield, R.J., (2000). Effects of photoperiod and maturity genes on plant growth, partitioning, radiation use efficiency and yield in soybean [Glycine max (L.) Merrill] 'Clark. Journal Annals of Botany 85: 335-343. 
[19] Eze, O. C. and Igwillo, U. C. (2018). Determination of Physical Properties of Afzelia africana Seeds. Journal of Experimental Research. Vol 6 No 1.35 - 44

[20] Fashina, A.B., (1996). Some physical and aerodynamic properties of seed as related to mechanical decortications. MSc Thesis, Department of Agricultural Engineering University of Ibadan, Nigeria

[21] Gathu, E.W., Karuri E.G. and Njage, P.M.K. (2012). Physical characterization of new advanced drought tolerant common bean (Phaseolus vulgaris) lines for canning quality. American Journal of Food Technology, 7(1): 22-28.

[22] Gharibzahedi SMT, Mousavi SM, Razavi SH, Akavan-Borna M (2009). Determination of nutritional and physical properties of sesame seed. Proc. 4nd Int. Conf. Rural Development, Vilnius, Lithuania.

[23] Gharibzahedi, S. M. T., Etemad, V., Mirarab-Razi, J., and Foshat, M. (2010). Study on some engineering attributes of pine nut (Pinus pinea) to the design of processing equipment. Research in Agricultural Engineering, 56, 99-106.

[24] Ghasemi V. M, Mobli H, A. Jafari, Keyhani AR, Heidari Soltanabadi M, Rafiee S, Kheiralipour K (2008). Some physical properties of rough rice (Oryza Sativa) grain. Journal of Cereal Science. 47:496-501.

[25] Gonçalves, E.M., Brazão, R, Pinheiro, J., Abreu, M.S., Cristina, L. M, C, Martins, M. M. (2005). Influence of maturity stage on texture, pectin composition and microstructure of pumpkin." In: Mercosur Congress on Process Systems Engineering, 4., Rio de Janeiro. Anais... Rio de Janeiro: Empromer,

[26] González de Mejía E, Valadez-Vega, M. D. C., Reynoso-Camacho, R., and Loarca-Pina, G. (2005). Tannins, trypsin inhibitors and lectin cytotoxicity in tepary (Phaseolus acutifolius) and common (Phaseolus vulgaris) beans. Plant Foods for Human Nutrition, 60(3), 137-145. https://doi.org/10.1007/s11130-005-6842-0

[27] Gupta, R. K. and Das, S. K. (2000). Fracture resistance of sunflower seed and kernel to compressive loading. Journal of Food Engineering, Dublin, v. 46, n. 2, 1-8.

[28] Gustustafson, T. and Kjelgard, P. (2000). Production and Preservation of Animal Feeds. Hill Book Company, New York.

[29] HarvestPlus. (2014). Biofortification Progress Briefs, (August), 82. Retrieved from http://www.harvestplus.org/content/new-progress-briefs-biofortification-released

[30] Heidarbeigi, K. Ahmadi, H., Kheiralipour, K. and Tabatabaeefar, A. (2009). Some physical and mechanical properties of Khinjuk. Pak. J. Nutr., 8 (1): $74-77$.

[31] Hu, Z., Zhang, H., Kan, G., Ma, D., Zhang, D., Shi, G. and Yu, D. (2013). Determination of the genetic architecture of seed size and shape via linkage and association analysis in soybean (Glycine max L. Merr.). Genetica, 141(4-6), 247-254.

[32] Ige M.T., (1997). Measurement of some parameters affecting the handling of losses of some varieties of cowpea. Agric. Eng. Res., 22:127-133.

[33] Ijadunola. J. (2015). Determination of Some Physical Properties and Terminal Velocity of Locust Beans of Parkia Specie (Parkia Biglobosa). Science and Engineering Perspectives SEP, 10(10), 105-111

[34] Indira, K, Dharmalingam, C. Seed development and maturation in fenugreek, Madras. Agric. J., 83: 1996, pp 239-240.

[35] Isah, A.B., Olorunsola, E.O. and Zaman, Y.E. (2012). Physicochemical properties of Borassus aethiopum starch. Asian Journal of Pharmaceutical and Clinical Research 3: 132 - 134.

[36] Ixtaina V.Y., Nolascoa S.M., and Tomas M.C., (2008). Physical properties of chia (Salvia hispanica L.) seeds. Industrial Crops and Products 28(3), 286-293.

[37] Jaeger, W. F., (1997). Mechanical Processing of Grains. Journal of Food Science 4(2): 6 - 8.

[38] Kara, M., Sayinci, B., Elkoca, E., Öztürk, İ. and Özmen, T.B. (2013). Seed size and shape analysis of registered common bean (Phaseolus vulgaris L.) cultivars in Turkey Using Digital Photography. Journal of Agricultural Sciences, 19(1): 219-23 
[39] Leterme, P., and Carmenza, M. L. (2002). Factors influencing pulse consumption in Latin America. The British Journal of Nutrition, 88 Suppl 3(January 2003), S251-5. https://doi.org/10.1079/BJN/2002714

[40] Lvin, J. B. (1971). Analytical evaluation of pressures of granular materials on silo walls. Powder Technology, 34( 35), 280-285.

[41] Marzo, F., Alonso, R., Urdaneta, E., Arricibita, F.J. and Ibanez, F. (2002). Nutritional quality of extruded kidney bean (Phaseolus vulgaris L. var. Pinto) and its effects on growth and skeletal muscle nitrogen fractions in rats. J. Anim. Sci., 80: 875-879.

[42] Mullah, S.K. (1992). The effect on moisture content on the physical properties of groundnut kernels. Tropical Science. 32: 129-136.

[43] Mohsenin, N.N. Physical Properties of Plant and Animal Materials, 2nd ed. Gordon and Breach Science Publishers, New York. 1986.

[44] Mpotokwane, S. M., Gaditlhatlhelwe, E., Sebaka, A., and Jideani, V. A. (2008). Physical properties of bambara groundnuts from Botswana. Journal of Food Engineering, 89(1), 93-98. https://doi.org/10.1016/j.jfoodeng.2008.04.006

[45] Nasar-Abbas, S. M., Plummer, J. A., Siddique, K. H. M., White, P., Harris, D., and Dods, K. (2008). Cooking quality of faba bean after storage at high temperature and the role of lignins and other phenolics in bean hardening. LWT - Food Science and Technology, 41(7), 1260-1267. https://doi.org/10.1016/j.lwt.2007.07.017

[46] Nciri, N., El Mhamdi, F., Ben I. H., Ben Mansour, A., and Fennira, F. (2014). Physical Properties of Three White Bean Varieties (Phaseolus vulgaris L.) Grown in Tunisia. Journal of Applied Science and Agriculture. 9. 195-200.

[47] Nimje, P.M. and Gandhi, A.P. (1994). Effect of stage of harvesting and nitrogen levels on yield and usitatissimum. Journal of Oilseeds Research., 11: 141-151.

[48] Omobuwajo, O.T., Akande, A.E. and Sann, A.L. (1999). Selected physical, mechanical and Aerodynamic Properties of African Breadfruit (Treculia africana) Seeds. J. Food Eng., 40: 241 244.

[49] Pieta, F. C., Ellis, R.H. (1991). The development of seed quality in spring barley in four environments: I. Germination and longevity. Seed Sci. Res. 1: pp 163-177

[50] Rodrigues JA, Ribeiro ND, Londero PMG, Filho AC (2005a). Correlation between water absorption and cooking time of bean cultivars. Rural Ciênc. 35 (1): 209-213

[51] Rodrigues JA, Ribeiro ND, Filho AC, Trentin M, Londero PMG (2005b). Quality for the cooking of bean grains obtained at different sowing times. Brag. 64 (3): 369-376

[52] Romano C, Helbig E, Rutz D, Shirmer MA, Elias MC (2005). Relationship between hydration curve and cooking time in beans (Phaseolus vulgaris L.) In: National Research Congress Feijão, 9, Goiânia, GO, Brazil. Proceedings. Embrapa

[53] Santalla, M., Fueyo, M.A., Rodino, A.P., Montero, I. and De Ron, A.M. (1999). Breeding for culinary and nutritional quality of common bean (Phaseolus vulgaris L.) in intercropping systems with maize (Zea mays L.). Journal of Biotechnology, Agronomy, Society and Environment 3: 225229.

[54] Sefa-Dedeh, S. and Stanley, D.W. (1979(. Textural implications of the microstructure of legumes. Food Technology, 33(10): 77-83.

[55] Shimelis, E.A. and S.K. Rakshit, (2005). Proximate composition and physico-chemical properties of improved dry bean (Phaseolus vulgaris L.) varieties grown in Ethiopia. LWT-Food Science and Technology, 38(4): 331-338.

[56] Siddique, A.B. and Wright, D. (2003). Effects of time of harvest at different moisture contents on seed fresh Weight, dry weight, quality (Viability and Vigour) and food reserves of peas (Pisum sativum L.). Asian Journal of Plant Sciences, 2: 983-992

[57] Singh, N., Kaur, M., Sandhu, K. S., and Guraya, H. S. (2004). Physicochemical, thermal, morphological and pasting Properties of Starches from some Indian black Gram (Phaseolus mungo L.) cultivars. Starch-Starke, 56(11), 535-544. https://doi.org/10.1002/star.200400290 
[58] Sirisomboon, P., Kitchaiya, P., Pholpho, T. and Mahuttanyavanitch, W. (2007). Physical and mechanical properties of (Jatropha curcas L.) fruits, nuts and kernels. Biosystems Engineering, 97(2): 201-207.

[59] Summerfield, R.J., Asumadu, H., Ellis, R.H., Qi, A. (1988). Characterization of the photoperiodic response of post-flowering development in maturity isolines of soabean [Glycine max (L.) Merrill] 'Clark. Journal Annals of Botany 82: 765-771

[60] Teshome, M. D. and Emire, S. (2012). Canning quality evaluation of common bean (Phaseolus vulgaris L.) varieties grown in the Central Rift valley of Ethiopia Derese. East African Journal of Science, 6(1), 65-78

[61] Van Loggerenberg, M., (2004). Development and application of a small-scale canning procedure for the evaluation of small white beans (phaseolus vulgaris). Ph.D Thesis, University of the Free State, Bloemfontein.

[62] Waziri, A.N. and Mittal, J.P. (1983). Design of related physical properties of selected agricultural products. J. Agric. Mechanization in Asia, Africa and Latin America (AMA.) 14(1): 59-62

*Corresponding author.

E-mail address: Oghene.prosper@ yahoo.com/ erobo2011@ gmail.com 